\section{British Columbia}

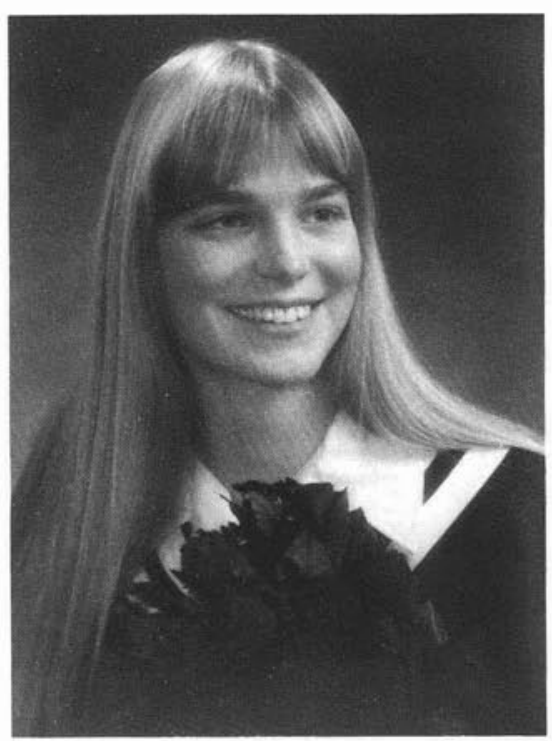

\section{CIF Medal Winner at UBC}

Mrs. Laurie L. Kremsater, a native of Vancouver, is the winner of the CIF medal at UBC in 1985. In addition to a distinguished academic record which includes leading her class in the last three years, and numerous awards and scholarships such as the H.R. MacMillan Scholarship in Forestry (twice), the Ken Haley Forest Fire Memorial Prize, the Forestry Summer Camp Scholarship, the Oscar Soderman Memorial Scholarship, the Banks Foundation Scholarship, the H.R. MacMillan Prize in Forestry and the Commonwealth Forestry Book Prize, Laurie is an accomplished soccer player, having played on both the varsity and intermural teams. Mostly however, she will be remembered for her open, pleasant, positive personality, her wit, and her contribution to numerous group and class projects. Laurie is interested in the relationships between wildlife and forestry practice and has chosen to continue her studies at UBC in that area.

\section{Spring Convocation \\ Recipients of Higher Degrees PhD}

Behera, N. Topochemistry of delignification and its effect on fiber properties on spruce organosolv pulp.

Brand, D. Early growth and development of Douglas-fir in relation to interspecific competition.

Ferreira, M. An analysis of the future productivity of Eucalyptus grandis plantations in the "Cerrado" regions in Brazil: A nutrient cycling approach.

\section{MSc}

Cushon, G. Gaseous nitrogen transformations in a mature forest ecosystem.

Kim, W.J. Influence of preservative treatment on durability of aca-treated white spruce poles.

McNay, S. Forest crowns, snow interception, and management of black-tailed deer winter habitat.

Vihnanek, R. The effects of slashburning on the growth and nutrition of young Douglas-fir plantations in some dry, salaldominated ecosystems.

\section{MF}

Cozens, R. Insect and disease risk factors in established interior spruce plantations.

Kiss, L. A study of five timber harvesting systems used for streamside logging.

\section{Undergraduate Degrees Awarded}

Sixty-nine BSF degrees were awarded, 7 with Honours

\section{Canadian Forestry Scholars Programme - 1985-86}

The following graduate students have been awarded scholarships under this CFS programme:

Ashcroft, G. Bracher, G.

Goh, J.

Higgins, E.

Jaffray, B.

James, C.

Morasse, $\mathrm{J}$

Penner, $\mathrm{M}$.

Richter, K

Schulting, $P$.

UBC candidates hold 12 out of the 50 CFS awards for 1985-86.

\section{Forest Policy in Alberta}

A weakness in the university contribution to forestry is that much worthwhile work by students, both graduate and undergraduate, never obtains the circulation that it deserves.

It is good, therefore, to see Alberta Energy and Natural Resources' publication of Peter Murphy's monumental History of Forest and Prairies Fire Control Policy in Alberta. This volume, which surely will be reviewed elsewhere in the Chronicle and which with 408 pages must surely set an all time record for a one-unit directed study, was researched and written by Professor Murphy as part of his doctoral programme at UBC. The term seminal is often loosely used by this is truly a seminal work that will surely be for many years to come a much quoted source on the history of not only fire control but the development of forestry in western Canada.

\section{Dr. Vladimir Krajina}

Dr. Krajina's many friends will be delighted to know that he has been further honoured. In June a scientific meeting in his honour was held at the University of Western Ontario as part of the annual Canadian Congress of Biology. Dr. Krajina has been fittingly described as "a Churchillian of the forest ecology world". His school of ecosystem classification increasingly forms a bridge between ecology and practical forest management and provides a sound ecological framework for more intensive forest management in the province, while his continuing advocacy has resulted in the British Columbia's setting aside more than one hundred ecological reserves.

\section{Retirement of Professor J.W. Walters}

During recent weeks there have been a series of special events to mark the retirement of Jack Walters. For many years Director of the UBC Research Forest, Professor Walters is one person for whom a biographical note is unnecessary. Throughout his career, Jack Walters has been a strong advocate of true professionalism and rational silvicultural management, and has been prominent in the profession both provincially and nationally. We wish him well in his retirement to the Welsh Border Country where, typically, he is setting himself to building a house and planting oak trees.

\section{Economic Entomology}

Our forest entomolgists work closely with the Department of Pestology at Simon Fraser University. It is therefore with pleasure that we note the award of the J.E. Bussart Memorial Award to Dr. John Borden of SFU. This most prestigious award for a researcher in economic entomology in North America was awarded to Dr. Borden received for work in ambrosia beetle management based on the use of pheremones.

\section{Papers and Meetings}

In April, Professor Golding presented papers at a BC Forest Service meeting on slope stability at Lorax Forestry School and at a Canadian Water Resources Association meeting at Kelowna.

Professor J.G.H. Smith chaired a symposium on Renewable Resource Management in the Pacific Northwest at the 1985 Northwest Scientific Association Conference held in May in Vancouver.

In May, Professor Marshall attended the Inland Growth and Yield Co-op advisory and steering group meetings in Spokane, and presented a paper entitled "Risk and uncertainty in timber supply modelling" at 
the ABCPF/FEPA - sponsored short course on "Modelling and Economics of Timber Supply".

In June, Professor F.L.C. Reed was invited to make a short presentation and answer questions before the Standing Committee on Forestry of the House of Commons. He also spoke at an Economic Development Conference at Cornerbrook, Newfoundland.

\section{International Forestry}

John Roper (BSF '70) who has spent the last year on a graduate programme at UBC as a CIDA Scholar has been appointed Regional Forestry Advisor for Latin America for CARE-International. Based on San Jose, Costa Rica, he will be responsible for the social forestry programmes currently underway in seven Latin American countries under CARE auspices.

\section{Surfacing of Trails}

During the past couple of years or so extensive use has been made of hog fuel to surface well trodden trails at the University Forest. This has attracted varied comment, from deep-felt appreciation by students walking them in bad weather to undisguised amusement by some of our more hard-nosed industrial foresters. A further angle was presented by a group of Chinese foresters who recently visited the forest. They were much impressed, for in their homeland hog fuel would be considered far too valuable to use for such a purpose.

\section{International Forestry - the lighter side}

In a recent term paper on International Forestry a student reported that "because of the proximity of the Indian Ocean and the Himalaya Mountains the plains of North India are very precipitous"

\section{J.V. Thirgood}

\section{Alberta}

\section{Staff Activities}

In June, Peter Murphy, Associate Dean of Forestry, visited the Universidad Nacional Agraria, La Molina, Peru to review their grad-degree program in forestry, recently established by CIDA. Peter was also present at the Ninth World Forestry Congress in Mexico.

Dr. Kare Hellum and Mr. John King, PhD candidate, attended the IUFRO meeting in Vienna, Austria in early June which dealt with 'seed formation under stressful conditions.' John King presented a paper at one of the working group sessions on Douglas-fir.

Drs. Paul Woodard and Ken Higginbotham, accompanied four graduate students to the Northwest Scientific Association meeting in Vancouver, B.C., in May. Graduate students Sue Michalsky and
John Berry presented papers on their research findings. Shortly thereafter Ken and Paul joined a tour of forest management activities in Quebec, sponsored by the Quebec provincial government and the Canadian Forestry Service. Dr. Woodard also attended the Fire and Forest Meteorology Conference in Detroit, Michigan.

Effective July 1, 1985, Drs. Ken Higginbotham and Steve Titus are each on a one-year sabbatical. Ken will be reviewing the provincial reforestation standards and consulting on operational silviculture for the Alberta Forest Service. Steve Titus will be researching statistical analysis methods and computer applications.

Dr. James Beck, Department Chairman, and graduate student Terry Kristoff were in Prince Albert, Saskatchewan to present their results of a pilot study on uses of computer-aided harvest scheduling models for timber supply analysis in Saskatchewan.

During May, Dr. James Butler directed a team of eight people at Pt. Pelee National Park on a study concerning the social and resource impacts resulting from the increasing popularity of birdwatchers. Pt. Pelee, Ontario has become one of the world's favorite locations to observe birds during spring migration. Shortly thereafter, Dr. Butler visited Genung Leuser National Park in northern Sumatra as an advisor on the management and education strategies for the rare Orang-utan.

Drs. Bruce Dancik and Adjunct Professor Francis Yeh attended a workshop at the Petawawa National Forestry Institute in May to discuss proposed developments in biotechnology.

\section{Visiting Scientists}

The University of Alberta recently welcomed Dr. Yrjo Norokorpi of the Rovaniemi Research Station, Finnish Forest Research Institute. Dr. Norokorpi was awarded a $\$ 25000$ university research grant to study wetland reforestation in Alberta until June 1986. Yrjo is a professor of silviculture at the University of Helsinki, and his doctoral thesis dealt with decay and decay-causing microbes in old spruce stands of northern Finland. His more recent research has focused on reforestation problems in northern Finland.

Recent visitors to the university were Dr. Geoffry B. Sweet, Dean of the School of Forestry, University of Canterbury, Christchurch, New Zealand, and Dr. Don Durzan, Chairman, Department of Pomology, University of California, Davis, California. In addition to visiting with forest genetics and biotechnology students and staff, $\mathrm{Dr}$. Sweet gave a special seminar sponsored by the Reforestation and Reclamation Branch of the Alberta Forest Service. The visits of Drs. Sweet and Durzan were made possible by the Alberta Forest Service and the Canadian Forestry Service.

\section{Douglas K. Krystofiak}

\section{New Brunswick}

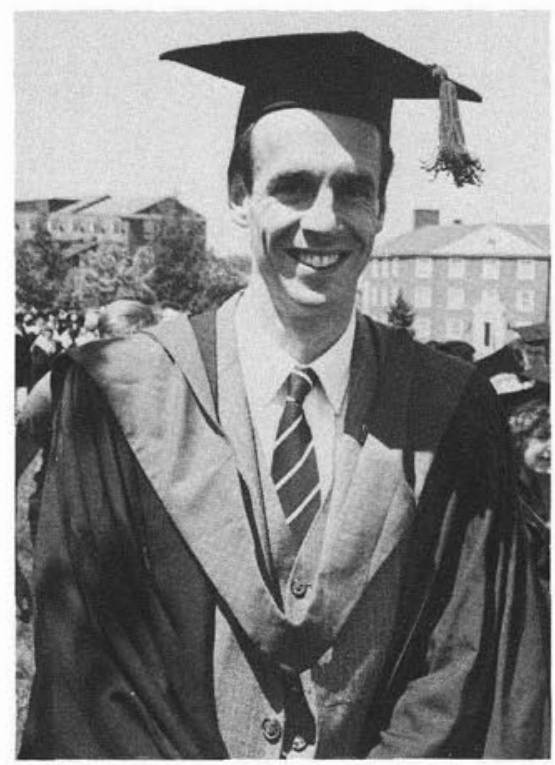

First Ph.D. in Forestry

Timothy James Butler Boyle is unique. $\mathrm{He}$ is the first recipient of the doctor of philosophy degree in forestry from UNB.

A native of Cardiff, Wales, and now a resident of Deep River, Ontario, Dr. Boyle first became interested in forestry as an undergraduate at the University of Edinburgh. One of the options for majors in ecological science in its bachelor of science program was forestry. After graduating, he worked in Wales for the British Forestry Commission in the forest management.

In January 1981, Dr. Boyle moved to Canada and started work with the Canadian Forestry Service at the Petawawa National Forestry Institute in Chalk River, Ontario. With CFS encouragement, he began studying for his MSc in forestry at UNB in September, 1981. After a year, he successfully completed the qualifying examination and proceeded with work at the Ph.D. level.

The subject of Dr. Boyle's Ph.D.thesis, is the mating system and population structure of black spruce in central New Brunswick. The study has a direct bearing on tree-improvement strategies for this commercially important species. The results of his work at UNB and with the Canadian Forestry Service will help determine what seedlings are used in reforestation of black spruce.

The spring issue of UNB Forestry Focus (Vol. 10 No. 2) appeared in June. Entitled "What Does A Geotechnical Engineer Do In the Woods? (besides hunt, hike and watch birds)", this issue's article was written by R.A. Douglas, forest engineering professor at UNB. Extra copies of the article are available free of charge as long as supplies last. 


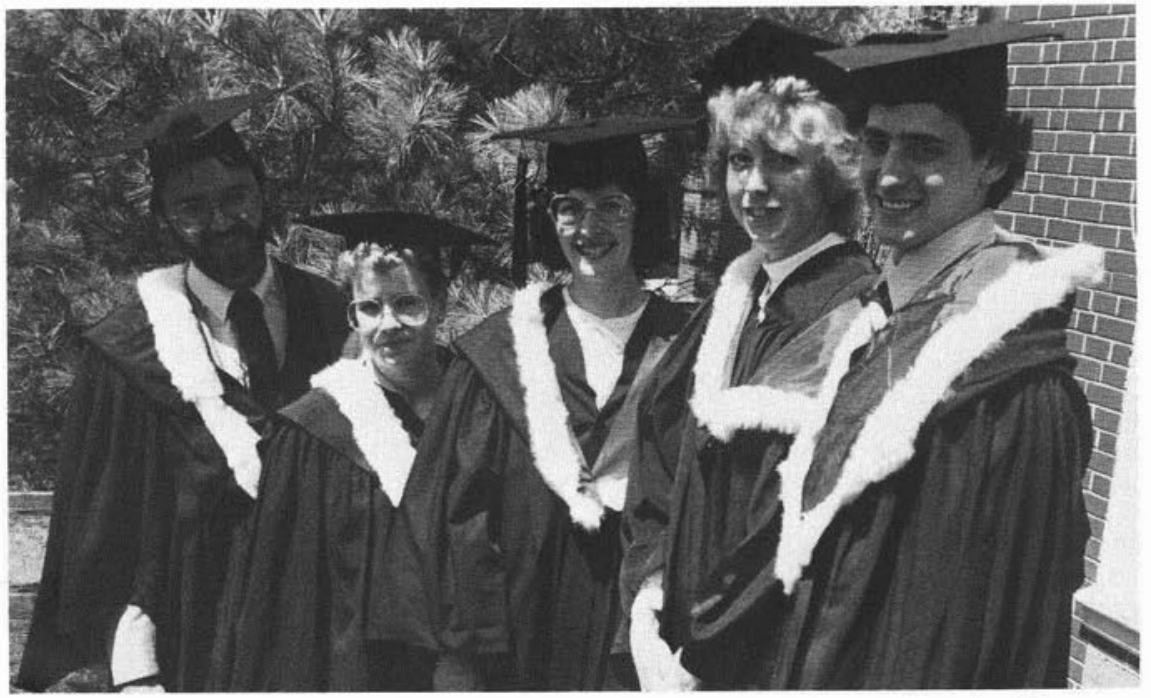

UNB's forestry prize winners (I. to r.): Tim Whynot, Judy Beck, Shelley Vescio, Alison Haworth and lan Taviss. Missing: Dan Blais.

\section{Students Win Prizes}

Awarded at this year's UNB graduation exercises (Encaenia) in May were the following:

Lieutenant-Governor's Silver Medal Ian H. Taviss, Montreal West, PQ

Canadian Institute of Forestry Merit Award - Shelley A. Vescio, Thunder Bay, ON

Commonwealth Forestry Bureau Book

Prize - Judith A. Beck, Montreal, PQ

Merlyn Stillwell Memorial Prize - Daniel

R.J. Blais, Sherbrooke, $P Q$

G.D. Estey Memorial Prize - Timothy W. Whynot, Italy Cross, NS

Videto-Hadley Memorial Prize - Alison

R. Haworth, St. Hilaire, PQ

\section{C.F. Bentley Award}

The C.F. Bentley Award, established in 1983 to recognize excellence of student presentations at the annual meeting of the Canadian Society of Soil Science, was won this year by Arlene B. Hilger, who recently finished her MScF program. Her paper "Availability of Iron and Aluminum Phytates to Myccorhizal and NonMyccorhizal Jack Pine Seedlings", given in Charlottetown in late June, earned her a certificate and a cheque for $\$ 500$.

Two further papers from UNB presented at the annual meeting were: "Effect of $\mathrm{pH}$ and Type of Forest Floor on Nitrification" (E. Robichaud, graduate student) and "Nitrogen Fertilizer Requirements of HighPerformance Hybrid Poplar on Prince Edward Island" (A.C. Miller, recent MScF recipient).

\section{Faculty Briefs}

Professor E.W. Robak, Forest Engineering, presented the following papers in April and May:

"Forest Operations Planning Decision Support: Status and Directions" - at a software fair sponsored by the Forest Resources Systems Institute (FORS) in Louisville, Kentucky;

"Forest Operational Planning in Canada: a New Approach" - at a IUFRO conference in Ireland; "OP-PLAN: a Forest Operational Planning Decision Support System" - at a meeting of the Canadian Operational Resources Society (CORS) in Halifax, Nova Scotia.

Professor M.R. Roberts, Forest Resources, presented the following poster in June:

"Predicting Diameter Distributions: a Test of the Stationary Markov Model" - at a meeting of the Ecological Society of America, held at the University of Minnesota, Minneapolis.

Professor E.J. Rickards, Forest Engineering, visited ergonomic research facilities at the Universities of Surrey, Birmingham, Nottingham and Loughborough, England, in May and June. Also in June, he attended the Fourth International Conference on Ergonomics in Manufacturing, held in Stuttgart, West Germany, and visited ergonomics research facilities at the Fraunhofer Institute of the University of Stuttgart.

Joanne E. MacDonald, who has been instructor and lecturer in forest plants for the past five years, is now a PhD candidate at the University of Victoria. She will be working under Dr. J.N. Owens on a colla- borative research project with MacMillanBloedel entitled "Dormancy Induction in Fall Planting of Stock of Coastal DouglasFir". Joanne was the winner of one of only two 1985-86 Bradfield Graduate Fellowships worth $\$ 18500$ each. These fellowships, sponsored by Noranda, are intended to promote research collaboration between Canadian universities and Noranda companies.

On her way to British Columbia, she presented the following paper in June: "Response of Red-Berried Elder to Clearcutting" (co-authored by G.R. Powell, UNB) at the Canadian Biological Congress in London, Ontario. Earlier in May, she conducted a UNB Continuing Education short course entitled "Mosses, Clubmosses and Wildflowers".

Professor T.C. Bjerkelund became a world traveller in July and August. At the Ninth World Forestry Congress in Mexico ("Forest Resources in the Integral Development of Society"), he presented a position paper entitled "Tree-Harvesting Infrastructure: Problems and Initiatives for their Solution" within the Technical Commission's framework of "Trends and New Contributions in Production and Productivity". He then spent nearly three weeks as a visiting lecturer at the Northeast College of Forestry, Department of Logging and Log Transport, Harbin, China.

\section{Continuing Education in Forestry}

Two events scheduled for May had to be cancelled. "A Spring Surprise", intended as a contribution to Fredericton National Forest Week activities, was called off at the eleventh hour because of a death in the instructor's family. The "Map and Compass" workshop for hunters and fishermen did not attract enough registrants.

All of the "Evenings" in Fredericton's Odell Park were conducted as scheduled in May and June. Some 140 persons attended the four programs which covered trees, shrubs and flowers hardy in the Fredericton area, landscape design, wildlife conservation and Fredericton's approach to the establishment and care of city trees.

Tentative plans for the $1985 / 86$ school year include workshops and seminars on the following topics: (1) wood-supply analysis in management planning; (2) microcomputers in forestry; (3) lumber kiln-drying: (4) "facing the media"; (5) "balsam-fir update"; (6) site-classification (including geology and plant identification); (7) ergonomics; (8) acid rain; (9) effective speechmaking using visuals; $(10)$ public relations and natural resources management. 


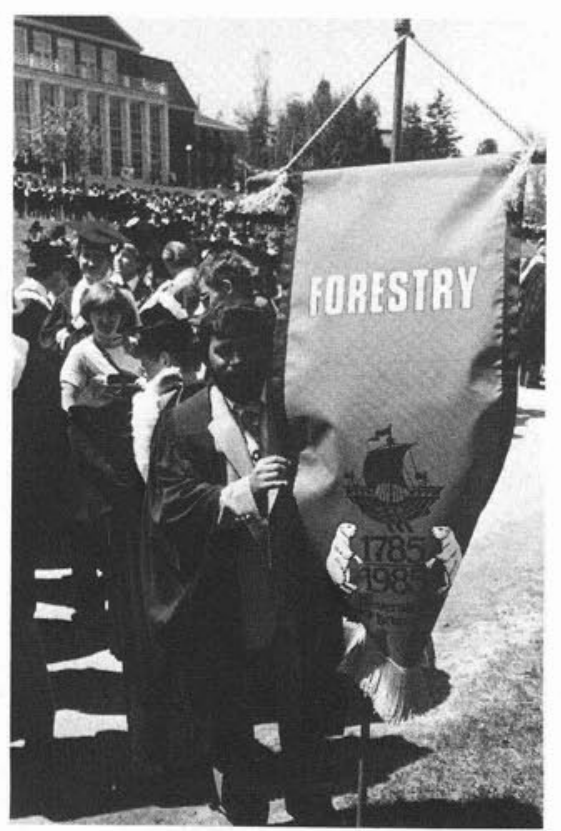

\section{Bicentennial Banners at UNB}

A new feature of UNB's Encaenia procession in May of this bicentennial year was the displaying of Roman-style banners by Faculty. Fourth-year student Doolar Ramlal of Trinidad proudly shows his Forestry ensign - black-and-white printing on a bright red background with gold cord and trim.

\section{Alex Dickson}

\section{Change of Address}

$\lambda$
Section
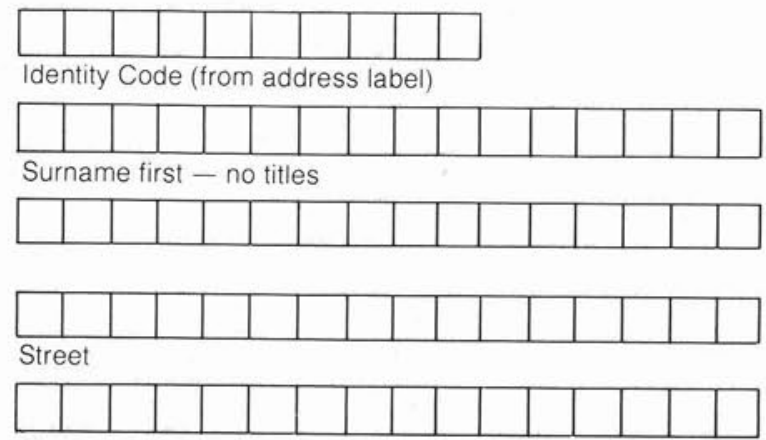

City and Province

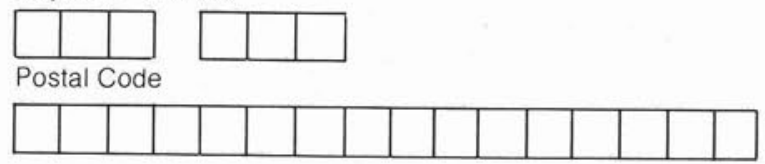

